\title{
FLUID HISTORY FROM CRYSTAL CAVITIES IN RAPAKIVI, PYTERLAHTI, SOUTHEASTERN FINLAND
}

\author{
KARI KINNUNEN, KRISTIAN LINDQVIST and RAIMO LAHTINEN
}

\begin{abstract}
KINNUNEN, KARI; LINDQVIST, KRISTIAN and LAHTINEN, RAIMO, 1987: Fluid history from crystal cavities in rapakivi, Pyterlahti, southeastern Finland. Bull. Geol. Soc. Finland 59, Part 1, 35-44.

The crystal cavities lined with quartz, feldspars, biotite, fluorite and a number of accessory phases occurring in the Haikonvuori pyterlite quarry in the Wiborg rapakivi massif were studied with mineralogical, petrographical and chemical methods. Primary fluid inclusions of quartz showed filling temperatures of $292^{\circ} \mathrm{C}$ to $342^{\circ} \mathrm{C}$. The cavities as structures are considered to be miarolitic vugs of chamber pegmatites, but their filling is interpreted as largely secondary and deposited during at least three of the fluid stages present. The nature of the filling material was not reflected in the chemical composition of the pyterlites, but the presence of the cavities, irrespective of their filling, could be inferred from the $\mathrm{La}$ and Th depletion and from various petrographic characteristics indicating intensified fluid action. Thus, crystal cavities seem to provide ideal fluid traps for studies of the local fluid history of the crust.
\end{abstract}

Key words: quartz, fluid inclusions, topaz, molybdenite, miarolitic, rapakivi, chemical composition, Finland, Virolahti, Pyterlahti, Haikonvuori.

Kari Kinnunen, Kristian Lindqvist and Raimo Lahtinen: Geological Survey of Finland, Kivimiehentie 1, SF-02150 Espoo, Finland.

\section{Introduction}

Rock cavities originally filled with fluid range in size from submicroscopic vacules and microscopic fluid inclusions via intergranular voids to giant fluid-filled spaces: vugs, pockets, cavities and eventually caves (see Richter and Simmons 1977; Fyfe et al. 1978; Roedder 1984). The larger cavities can be genetically considered as very large fluid inclusions, and in their pristine stage they may contain daughter minerals crystallized out from the fluid. However, because of their polycrystalline walls, the cavities have almost always leaked and are thus contaminated with later fluids present in the crust during uplift. Part of this long fluid history from cavity wall crystallization to supergene solutions present in the final weathering of the outcrops is reflected in the present filling: crystals of different generations are intermingled with various "clays".

In rapakivi granites these larger voids are present as small miarolitic vugs, which can be explained partly as enlarged intergranular voids into which the crystal faces of the rock-forming minerals protrude, and partly as larger crystal cavities characteristic of chamber pegmatites. In these now empty voids the rock-forming 


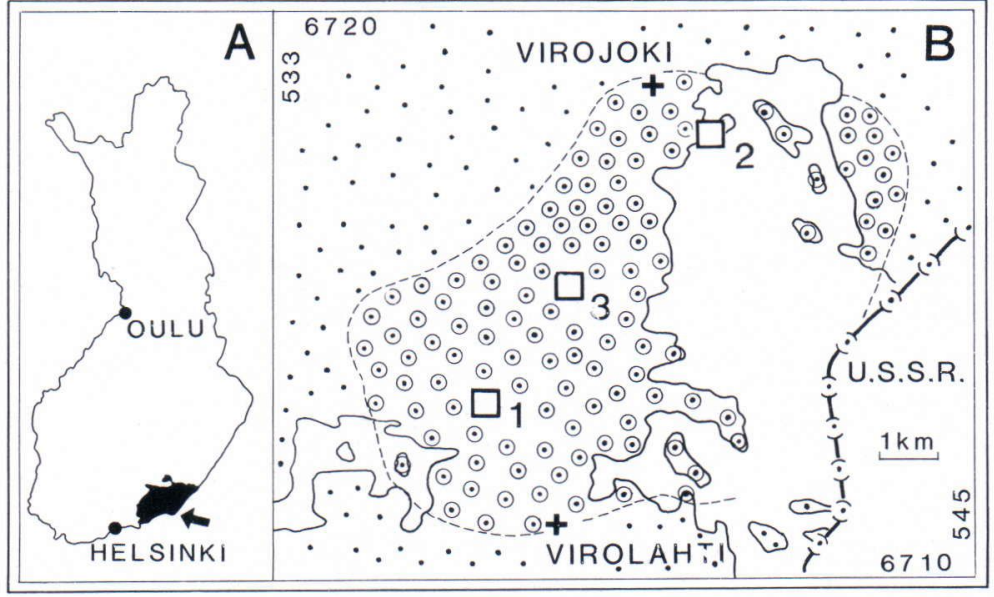

Fig. 1. A, Index map of Finland showing the Finnish part of the Wiborg rapakivi massif (black) and the Pyterlahti area (arrow). B, simplified geological map of the Pyterlahti area (Härme 1980). Rapakivi quarries: 1. Sysimäki (without known cavities), 2. Hevonniemi (with cavities), 3. Haikonvuori (with abundant cavities). The rapakivi surrounding the pyterlite area (circled dots) is principally wiborgite (dots). minerals protrude into the cavity, where they constitute the wall material. Phases deposited from the original fluid form the daughter crystals. Several younger fluid types have wholly or partly dissolved earlier phases (especially the water-soluble ones) and deposited new secondary minerals and colloidal masses. In this respect the common quartz crystal cavities of Finnish rapakivi granites are of particular interest, because they contain evidence that several fluid types flowed into and out of the cavities after their formation together with the host rapakivi.

Only a few studies have been conducted on the quartz crystal cavities common in the $\mathrm{Wi}$ borg rapakivi massif (see the literature in Härme 1980 b, p. 47), even though many of them contain interesting crystal specimens and hydrothermal ore minerals. The present study describes quartz crystal cavities associated with molybdenite and topaz crystals, recently found in the Haikonvuori pyterlite quarry (worked for dimension stones) in Pyterlahti, the municipality of Virolahti (Fig. 1). The crystal specimens were collected in 1981-84 from about ten cavities and crystal-lined fractures exposed during routine quarrying. Rock samples were collected from Haikonvuori and from two other granite quarries, Hevonniemi (with cavities) and Sysimäki (without known cavities), situated within the area of pyterlitic rapakivi in Virolahti (Fig. 1).

\section{Cavities and crystallization}

In Haikonvuori quarry the quartz crystal cavities had a narrow pegmatitic lining exhibiting the intergrowth textures (graphic granite) typical of granitic pegmatites. The mineral content

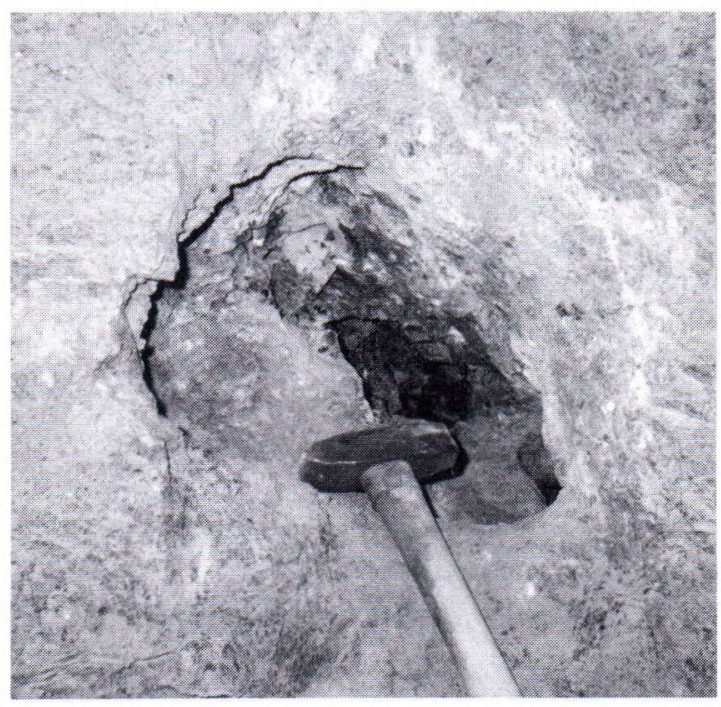

Fig. 2. Typical quartz crystal cavity in Haikonvuori quarry. Diameter ca. $3 \mathrm{dm}$. Most crystals removed. 
Table 1. Main component analysis of pyterlites and chamber pegmatite from Pyterlahti. Contents in weight percentages.

\begin{tabular}{lccccc}
\hline & 1 & 2 & 3 & 4 & Method \\
\hline $\mathrm{SiO}_{2}$ & 74.86 & 75.43 & 74.39 & 73.35 & $\mathrm{a}$ \\
$\mathrm{Al}_{2} \mathrm{O}_{3}$ & 12.39 & 11.63 & 12.19 & 13.59 & $\mathrm{a}$ \\
$\mathrm{Fe}_{2} \mathrm{O}_{3}$ (tot) & 2.80 & 2.31 & 3.00 & 2.01 & $\mathrm{a}$ \\
$\mathrm{MgO}_{\mathrm{CaO}}$ & 0.48 & 0.34 & 0.42 & 0.29 & $\mathrm{a}$ \\
$\mathrm{Na}_{2} \mathrm{O}$ & 0.90 & 0.85 & 0.89 & 0.92 & $\mathrm{a}$ \\
$\mathrm{K}_{2} \mathrm{O}$ & 3.65 & 2.96 & 3.22 & 3.29 & $\mathrm{a}$ \\
$\mathrm{MnO}_{\mathrm{TiO}}$ & 5.55 & 5.20 & 5.64 & 5.92 & $\mathrm{a}$ \\
$\mathrm{P}_{2} \mathrm{O}_{5}$ & 0.03 & 0.00 & 0.00 & 0.00 & $\mathrm{a}$ \\
$\mathrm{Sum}$ & 0.26 & 0.24 & 0.29 & 0.17 & $\mathrm{a}$ \\
$\mathrm{Rb}_{\mathrm{Zr}}$ & 0.05 & 0.00 & 0.03 & 0.00 & $\mathrm{a}$ \\
$\mathrm{Ba}$ & 00.98 & 98.97 & 100.08 & 99.55 & \\
$\mathrm{~F}$ & 0.023 & 0.033 & 0.037 & 0.034 & $\mathrm{~b}$ \\
$\mathrm{FeO}$ & 0.08 & 0.07 & 0.023 & 0.024 & $\mathrm{~b}$ \\
\hline
\end{tabular}

Samples:

1. Pyterlite, Sysimäki quarry, $\quad X=6713.5, Y=536.2$

2. Pyterlite, Hevonniemi quarry, $X=6718.1, Y=540.2$

3. Pyterlite, Haikonvuori quarry, $X=6715.3, Y=538.0$

4. Pegmatite, Haikonvuori quarry, $X=6715.3, Y=538.0$

Methods:
a. XRF analysis of lithiumtetraborate melts
b. Powder XRF analysis
c. Ion specific method with $\mathrm{F}$ electrode
d. Titration with potassium dichromate

depended on the size of the cavity, which varied from a few millimetres to some decimetres (Fig. 2). The smallest cavities lacked the minerals interpreted as contamination in the larger cavities; secondary late hydrothermal phases, supergene deposits from groundwaters and recent detrital sediments were deposited at the time the cavity was opened to a cave. The smallest cavities were usually composed only of the protruding wall minerals (feldspars, quartz, biotite and often fluorite), and can be interpreted as pure miarolitic cavities.

The analytical data (Tables 1, 2 and 3) show no significant chemical or mineralogical differences between the samples taken from differ-
Table 2. Trace element analyses of pyterlites and chamber pegmatite from Pyterlahti. Contents in ppm.

\begin{tabular}{|c|c|c|c|c|c|}
\hline & 1 & 2 & 3 & 4 & Method \\
\hline B & $<20$ & $<20$ & $<20$ & $<20$ & $\mathrm{a}$ \\
\hline $\mathrm{Bi}$ & $<10$ & $<10$ & $<10$ & $<10$ & $\mathrm{a}$ \\
\hline $\mathrm{Co}$ & 2.3 & 2.5 & 2.3 & 2.1 & $\mathrm{~b}$ \\
\hline $\mathrm{Cu}$ & 4.4 & 5.1 & 5.4 & 4.4 & $\mathrm{~b}$ \\
\hline $\mathrm{Ga}$ & 24 & 24 & 25 & 28 & $\mathrm{a}$ \\
\hline $\mathrm{Ge}$ & $<10$ & $<10$ & $<10$ & $<10$ & a \\
\hline $\mathrm{La}$ & 180 & 120 & 82 & 49 & b \\
\hline $\mathrm{Li}$ & 50 & 51 & 51 & 62 & b. \\
\hline Mo & $<5$ & $<5$ & $<5$ & $<5$ & $\mathrm{a}$ \\
\hline $\mathrm{Nb}$ & $<200$ & $<200$ & $<200$ & $<200$ & $\mathrm{a}$ \\
\hline $\mathrm{Ni}$ & 0.0 & 0.8 & 0.3 & 0.0 & b \\
\hline $\mathrm{Pb}$ & 56 & 60 & 58 & 57 & b \\
\hline $\mathrm{Sc}$ & 2.4 & 2.8 & 2.9 & 0.5 & $b$ \\
\hline $\mathrm{Sn}$ & 9 & 8 & 9 & 8 & $\mathrm{a}$ \\
\hline $\mathrm{Sr}$ & 78 & 83 & 70 & 78 & b \\
\hline $\mathrm{Th}$ & 36 & 31 & 26 & 14 & b \\
\hline V & 5.7 & 5.4 & 6.3 & 5.8 & b \\
\hline W & 6 & 4 & 7 & n.d. & $\mathrm{c}$ \\
\hline Y & 72 & 62 & 69 & 49 & $b$ \\
\hline $\mathrm{Yb}$ & 7 & 6 & 6 & 5 & $\mathrm{a}$ \\
\hline $\mathrm{Zn}$ & 69 & 79 & 78 & 81 & $b$ \\
\hline
\end{tabular}

Samples as in Table 1.

\section{Methods:}

a. Optical emission spectrographic analysis

b. ICP-OES analysis after total dissolution $(\mathrm{HF}+\mathrm{AR}+$ $\mathrm{HClO}_{4}$ )

c. Spectrophotometric determination using zinc dithiol n.d.: not determined

ent quarries (see Fig. 1). However, in the trace element composition there is a systematic decrease in the contents of $\mathrm{La}$ and $\mathrm{Th}$ from pyterlite sample 1 (without known cavities) through sample 2 (with cavities) to sample 3 (with many cavities). Light rare-earth elements (LREE) can act as compatible elements in very felsic magmas and diminish rapidly in abundance as differentation progresses (Miller and Mittlefehldt 1982). The depletion of La could refer to the most differentiated part of the pyterlite cupola while indicating the presence of cavities. A few accessory minerals (allanite, monazite) have proved to be important reservoirs for LREE in felsic magmas (Mittlefehldt and Miller 1983; 
Table 3. Petrographical analyses of the pyterlite samples listed in Tables 1 and 2.

\begin{tabular}{lccl}
\hline & 1 & 2 & 3 \\
\hline Quartz & $\mathrm{M}$ & $\mathrm{M}$ & $\mathrm{M}$ \\
K-feldspar & $\mathrm{M}$ & $\mathrm{M}$ & $\mathrm{M}$ \\
Plagioclase & $\mathrm{M}$ & $\mathrm{M}$ & $\mathrm{M}$ \\
Biotite & $\mathrm{m}$ & $\mathrm{m}$ & $\mathrm{M}$ \\
Chlorite & $\mathrm{a}$ & $\mathrm{a}$ & $\mathrm{a}$ \\
Zircon & $\mathrm{a}$ & $\mathrm{a}$ & $\mathrm{a}$ \\
Fluorite & $\mathrm{a}$ & $\mathrm{a}$ & $\mathrm{a}$ \\
Apatite & $\mathrm{a}$ & $\mathrm{a}$ & $\mathrm{a}$ \\
Haematite & $\mathrm{a}$ & $\mathrm{a}$ & $\mathrm{a}$ \\
Metamicts & $\mathrm{a}$ & $\mathrm{a}$ & $\mathrm{a}$ \\
Sericite & $\mathrm{a}$ & $\mathrm{a}$ & $\mathrm{a}$ \\
Calcite & - & $\mathrm{a}$ & $\mathrm{a}$ \\
Ilmenite & - & $\mathrm{a}$ & $\mathrm{a}$ \\
Magnetite & - & $\mathrm{a}$ & - \\
Chalcopyrite & - & $\mathrm{a}$ & - \\
Pyrite & - & - & $\mathrm{a}$ \\
\hline
\end{tabular}
M. major mineral, $>10 \%$
m. minor mineral, $5-10 \%$
a. accessory mineral
- mineral not observed
1) other than zircon

Table 4. Structural types of the alkali feldspars in Haikonvuori quarry determined by X-ray diffraction methods according to Goldsmith and Laves (1954).

\begin{tabular}{clc}
\hline Specimen & Structural type & Obliquity \\
\hline 1 & Orthoclase only & \\
2 & Orthoclase only & \\
3 & Maximum microcline & 0.83 \\
4 & Maximum microcline & 0.84 \\
5 & Maximum microcline & 0.95 \\
\hline
\end{tabular}

Specimens:

1. Alkali feldspar from an ovoid centre in pyterlite.

2. Alkali feldspar from pegmatite.

3. Alkali feldspar occurring together with molybdenite in cavities.

4. Alkali feldspar from pegmatitic rind surrounding the cavities.

5. Centre of a giant alkali feldspar crystal from a cavity.

Gromet and Silver 1983). Petrographic observations show that the metamict accessory crystals occur mainly as inclusions in the alkali feldspar ovoids in pyterlite sample 1 (without known cavities) but are enriched in the later biotite aggregates in pyterlite samples 2 and 3 (with cavities). The few samples leave this question to be answered in future work.

The presence of cavities in pyterlite was inferred from petrographic features (Fig. 3): quartz-biotite symplectites, microcavities and widespread microclinization indicating the action of fluids against the host rock. Augustithis (1973, Figs. 221-223) has described similar myrmekitic textures in biotite, which he attributed "to infiltration of quartz-forming solutions into the biotite". According to Vorma (1971), microclinization in rapakivi granites indicates high fluid pressure favouring the transformation of primary orthoclase to maximum microcline. X-ray diffraction studies of alkali feldspar specimens from Haikonvuori quarry reveal the same trend (Table 4): the obliquity of the alkali feldspars increases towards the cavity

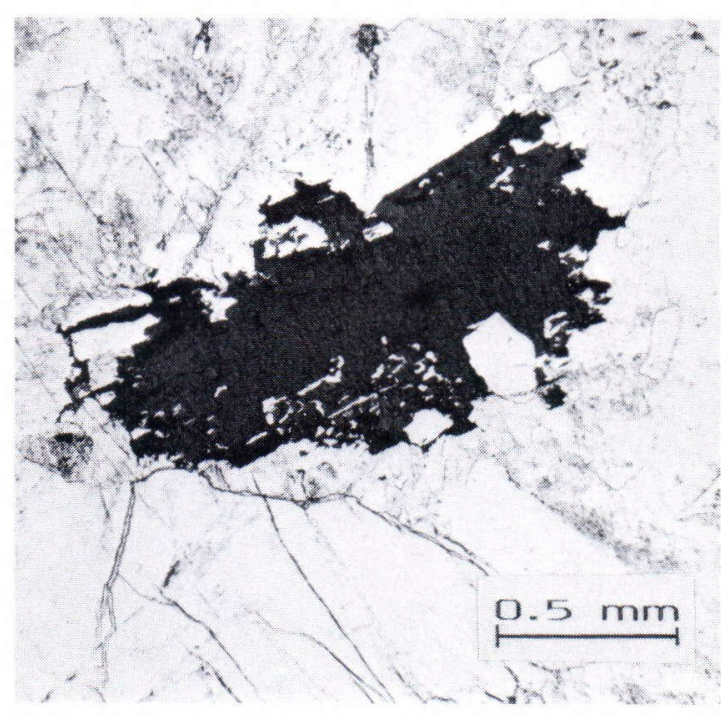

Fig. 3. Photomicrograph of the symplectitic texture bordering the biotite grain in pyterlite host rock in Haikonvuori. Clear grains are quartz and the pigmented ones alkali feldspar (mostly microclinized). Note the numerous microcracks depicting the action of hydrothermal fluid(s). Transmitted light with one polarizator. 
centre, indicating intensified action of the hydrothermal fluid medium in the crystallization process.

At Haikonvuori, the cavity crystallization was found to have begun with the formation of microcline and quartz as large crystals measuring up to several decimetres, together with albite laths, biotite, violet fluorite, platy haematite, black tourmaline, green beryl and topaz. The following minerals were deposited in the cavities and fractures during at least two hydrothermal stages: calcite (usually colourless) in three generations; pyrite as pyritohedron and as combinations of cube and pyritohedrons (with oscillatory growth); platy molybdenite; anhedral galena; vermicular chlorite; spherulitic marcasite and colloformic goethite.

\section{Cavity minerals}

\section{Quartz}

Quartz was the principal crystalline material of the cavities at Haikonvuori. The length of the crystals varied from a few millimetres to some decimetres. The habitus was long-prismatic and the crystals were ideal, the rhombohedral crystal planes being of almost equal size in each crystal. Most crystals lacked pyramidal faces, and the line connecting the nucleation centre to the present centre of gravity was in most crystals parallel to the c-axis. Individual quartz crystals were twinned according to the Dauphine law. This was seen from the natural etch markings on the prism and rhombohedral faces. Surface markings did not reveal the former presence of any late water-soluble, rare-mineral daughter crystals. Contact twins between quartz crystals were too rare to be determined for their twinning laws.

The quartz crystals varied from colourless to smoky. The darkest variety (morion) was found to contain $200-500 \mathrm{ppm} \mathrm{Al}$ (determined with optical emission spectrographic analysis). Doubly-polished plates revealed growth zoning in the quartz crytals, with smoky zones alternating with clear zones. In the outer parts of the crystals tourmaline needles occurred as primary mineral inclusions. The prism faces of the quartz crystals were nearly always etched to a matt gloss, but the rhombohedral faces were in places overlain by a later unetched quartz layer. Haematite globules were present on the contact plane of these two quartz types.

At room temperature, the primary and pseudosecondary fluid inclusions in the quartz crystals were composed of liquid, vapour and of four solid phases, three of which were anisotropic and transparent. One of these transparent phases shows its lowest refractivity index in the range of the inclusion brine, thus proving the presence of an unknown but water-soluble rare-mineral daughter crystal (cf. the lists in Phillips and Griffen 1981). The fourth solid phase was opaque, non-magnetic and under dark-field incident light, revealed red inner reflections indicative of haematite. Recrystallized (with necking down) pseudosecondary inclusion cavities occasionally contained halite cubes (isotropic and index of refraction within the range of those of quartz). The secondary fluid inclusions of hydrothermal type were composed of liquid, vapour and of two anisotropic and transparent crystal aggregates. Monophase secondary fluid inclusions were composed of liquid only, and they were observed together with chlorite and goethite spherules in the microfractures cutting all the earlier textures. The monophase secondary inclusions are probably supergene in origin.

During heating experiments (Leitz 350 and Chaixmeca stages) the primary inclusions were filled with liquid at $292^{\circ}-342^{\circ} \mathrm{C}$. Large inclusion cavities decrepitated at $320^{\circ}-350^{\circ} \mathrm{C}$. The secondary inclusions were filled with liquid at $134^{\circ}-167^{\circ} \mathrm{C}$.

Most of the primary and pseudosecondary inclusion cavities were in the shape of negative 


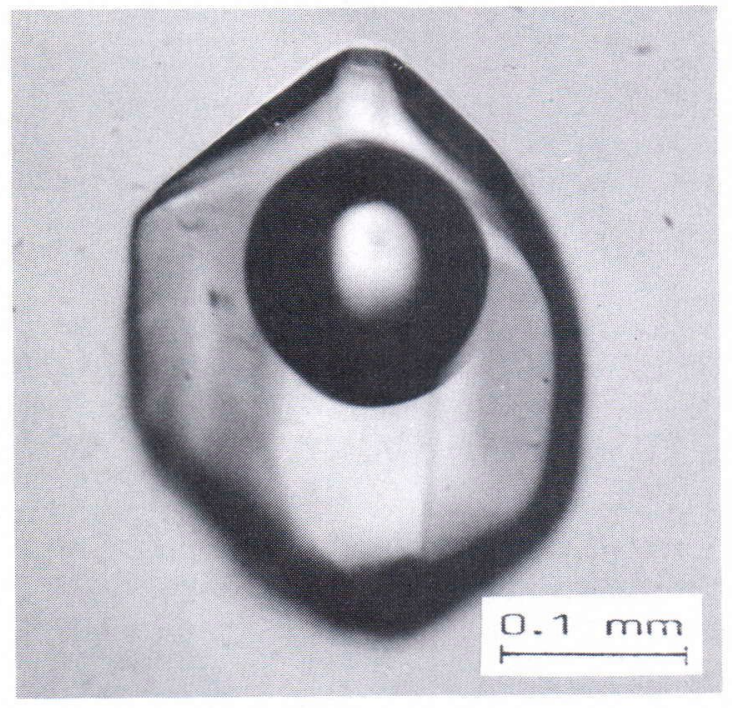

Fig. 4. Photomicrograph of a negative crystal in smoky quartz from Haikonvuori quarry. The primary fluid inclusion filling the cavity is composed of liquid, a vapour bubble and four solid phases (out of focus). Note the untwinned prism faces without striations and the curved rhombohedral ends in this negative crystal resembling in the main form (c/a ratio), its host quartz crystal. Transmitted plane-polarized light.

crystals consisting of short planar prism faces and weakly curved rhombohedral faces. The prism faces of the negative crystals did not have the twinning striations typical of quartz (Fig. 4).

The filling temperature range, $292^{\circ}-342^{\circ} \mathrm{C}$, of the primary fluid inclusions in the quartz from the Haikonvuori cavities is considered the lowest possible temperature of crystallization. The fact that the inclusion assemblages bear no visible indications of boiling can be interpreted as a sign that the fluid pressure exceeded $0.1 \mathrm{~kb}$. At about this pressure inclusions with filling temperatures of $292^{\circ} \mathrm{C}$ to $342^{\circ} \mathrm{C}$ would have boiled according to the thermodynamic relations calculated by Haas (1971). Vorma (1971) has estimated that the lithostatic pressure during the formations of the Wiborg rapakivi massif was about $1 \mathrm{~kb}$. If this figure is taken as the maximum fluid pressure during the pegmatitic stage, the estimated range $(0.1-1 \mathrm{~kb})$ raises the pressure-corrected temperature of crystallization to $312^{\circ}-464^{\circ} \mathrm{C}$ with the nomograms by Potter (1977). The very existence of cavities makes $2 \mathrm{~kb}$ a likely maximum pressure in theory, because, as shown in the differential strain analysis by Feves et al. (1977), most open fractures would close mechanically at lighter lithostatic load.

The Al content of Haikonvuori quartz, 200500 ppm, may offer a pressure-independent geothermometer. When the $\mathrm{Al}$ content is plotted on the diagrams of Dennen and Blackburn (1970), the minimum crystallization temperature obtained for Haikonvuori quartz rises to as much as $740^{\circ} \mathrm{C}$. This is clearly excessive, as can be inferred from the fluid inclusion data and from the lack of high-quartz habitus in the earliest phantom generations. Very dark quartz (morion, see Webster 1983) tends to contain a few thousand ppm Al (Frondel 1962). According to laboratory synthesis, the smoky colour of quartz is caused by the colour centres formed by natural irradiation with gamma-rays on $\mathrm{Al}^{3+}$ ions substituting for $\mathrm{Si}^{4+}$ ions in the quartz lattice (Nassau 1983, pp. 190-192).

\section{Topaz}

An unusual feature of the Haikonvuori cavities was the occurrence of topaz as transparent colourless or brownish crystals (length generally $1-2 \mathrm{~cm}$ ) and as translucent greenish fragments (length of largest $2 \mathrm{dm}$ ). It has been shown in experiments that, as with smoky quartz, natural irradiation with gamma-rays also causes the brownish color centres on colourless topaz (Nassau 1983, p. 200; Aines and Rossman 1986). The mineral inclusions consisted of tourmaline needles in the outer crystal zones and of spherulitic chlorite in the fracture fillings and on some crystal faces. No definitive primary fluid inclusions were found, although secondary fluid inclusions were common. Typical inclusions are needle-like tubes extending 


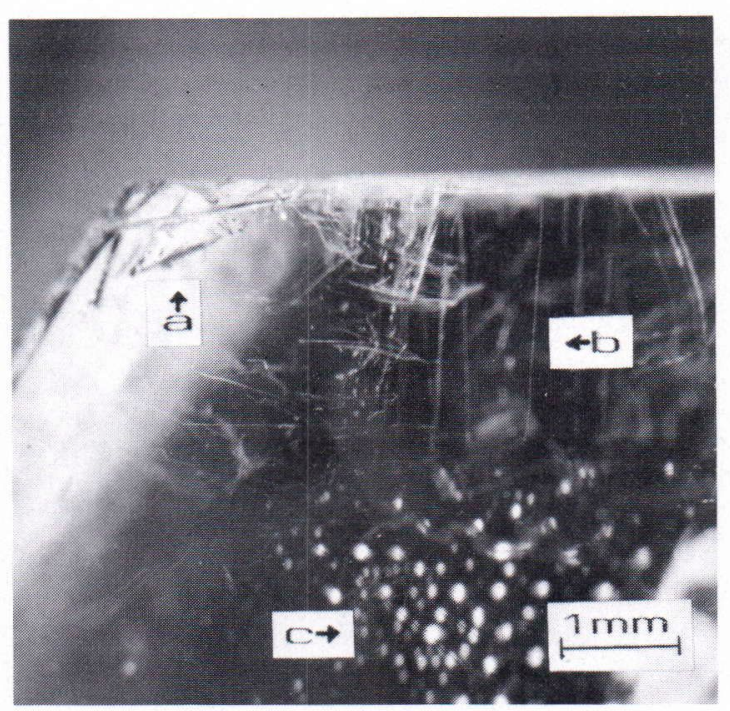

Fig. 5. Photomicrograph of typical inclusions in the transparent topaz from Haikonvuori: a) tourmaline needles, b) needle-like tubes, c) curved surfaces of secondary fluid inclusions. Dark-field illumination.

from the prism faces to the inner crystal zones (Fig. 5). These inclusions may be interpreted as dislocations that were later hydrothermally etched to become optically visible tubes (cf. Fig. 9 in Carstens 1968; Fig 4 in Eadington and Wilkins 1980; Fig. 2-23 in Roedder 1984). Most of the transparent crystals are cleaved along the basal plane and generally etched. Typical specimens therefore revealed only striated prism faces and deeply etched fracture and cleavage surfaces.

In addition to the above topaz types, large (up to $5 \mathrm{~cm}$ ) brownish and water-clear crystal fragments are said to have been found in the cavities of Haikonvuori. Unfortunately, we did not find any gem-quality material there and so are unable to confirm this information. However, we were able to borrow some of these crystals (rough and cut) for study. They contain goethite in the microfractures in a very specific spherule form. Interestingly, similar inclusions are described as typical of the brownish yellow topaz of Ouro Preto, Brazil, in the authorative atlas on inclusions in gemstones from different

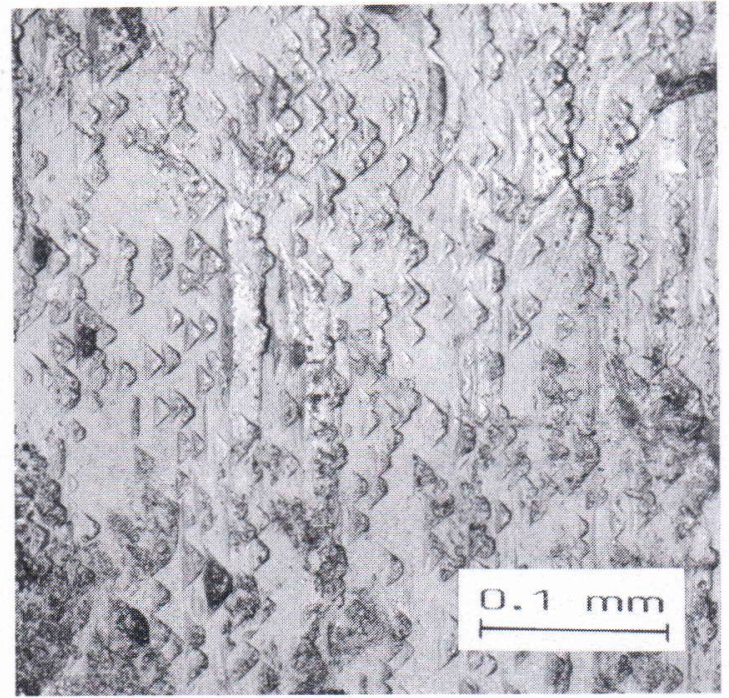

Fig. 6. Photomicrograph with incident light of the (120) prism face of topaz from the cavities of Haikonvuori quarry. The crystal face is covered with natural triangular and trapezium-shaped etch pits.

localities compiled by Gübelin and Koivula (1986, pp. 202 and 389).

The crystal surfaces of the Haikonvuori topaz were covered with etch pits resulting from the corrosive action of a hydrothermal fluid (Fig. 6). On (120) prism faces the morphology of the etch pits corresponded to the triangular and trapezium-shaped types described by Joshi and Taku (1972); the large, semi-circular pits resulting from prolonged hydrothermal corrosion were not found. The matt gloss of the prism faces of the Haikonvuori topaz is due to the numerous etch pits.

\section{Molybdenite}

Molybdenite occurs as euhedral, hexagonal platelets about $0.2 \mathrm{~mm}$ thick and up to about 4 $\mathrm{cm}$ long. Molybdenite was found in the cavities only as secondary, late-hydrothermal filling material, usually together with calcite in the fractures associated with the cavities. The simultaneous growth of molybdenite and calcite 


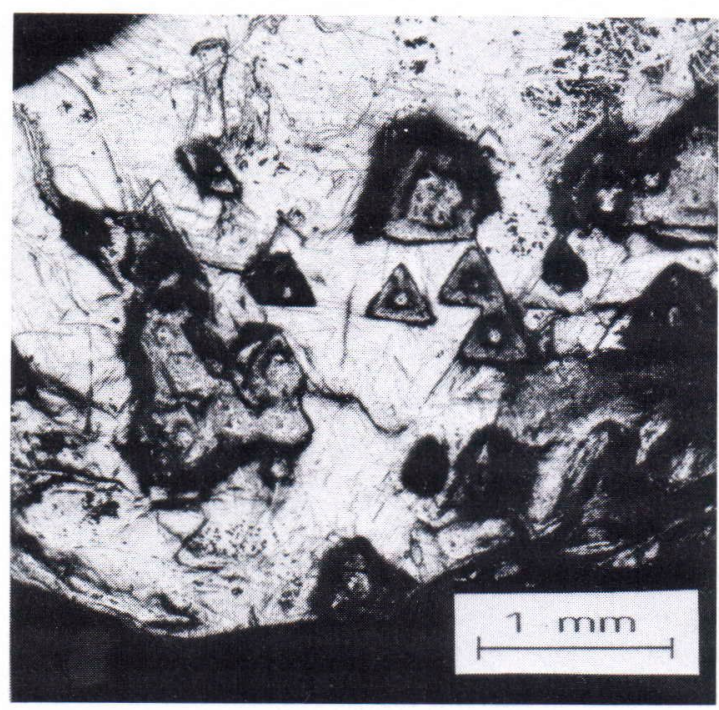

Fig. 7. Photomicrograph with incident light from the pinacoidal face of molybdenite from the cavities of Haikonvuori quarry. The dark pits are negative imprints of calcite crystals.

is demonstrated by the crystal growth figures seen on the pinacoid faces of the molybdenite platelets (Fig. 7). The most common texture is composed of pits resulting from the negative calcite crystal imprints, some of which are trigonal in shape. Corresponding positive forms were observed on calcite crystal plates. Natural etch pits were observed on pinacoid faces as triangular pits but they were only a few micrometres in diameter, testifying to the late hydrothermal genesis of molybdenite. Trace element analysis of molybdenite revealed the presence of $\mathrm{Ag}, \mathrm{Pb}, \mathrm{Cu}, \mathrm{Bi}, \mathrm{Ni}$ and $\mathrm{Zn}$, each in the range of 10-100 ppm, and also of W and Re, but both below the detection limit, $200 \mathrm{ppm}$ (AAS and OES methods, respectively).

\section{Discussion}

The quartz crystal cavities in the Wiborg rapakivi massif are usually interpreted as miarolitic (Wahl 1925, p. 60). There is a problem, however, in that not enough silica dissolves in the fluid to deposit the observed quantities of quartz in closed cavities, because in hydrothermal systems quartz is usually deposited as a result of a drop in temperature. A drop of $800^{\circ}$ to $400^{\circ} \mathrm{C}$ is not sufficient for depositing more than $0.3 \mathrm{wt} . \% \mathrm{SiO}_{2}$. This estimate is based on the experimental data of Kennedy (1950). F and B in the system may increase the solubility of $\mathrm{SiO}_{2}$, but only to about 1 wt. \% (Pichavant 1979; Manning 1983). In the same way $F$ and $B$ increase the exsolution of $\mathrm{H}_{2} \mathrm{O}$ from the pegmatitic melt (London 1986). It seems that the volume of fluid needed to produce the observed quantities of quartz and other silicate crystals should far exceed volume of the original cavity. In miarolitic crystallization the fluid inclusion assemblages of quartz should indicate the coexistence of fluid and a magma phase (devitrified glass inclusions together with ordinary fluid inclusions) and a high trapping temperature, $750^{\circ}-800^{\circ} \mathrm{C}$ (Olsen and Griffen 1984). These features were not observed in the quartz of the Haikonvuori cavities or in their pegmatitic rim material. Moreover, the colour zoning of the Haikonvuori quartz crystals shows that the fluid environment was subject to pulses (PTX). Vorma and Paasivirta (1979) have interpreted the multizoned zircons of the Laitila rapakivi massif in western Finland as indicating changes in the $\mathrm{H}_{2} \mathrm{O}$ pressure. Situated in the biotite aggregates altered by hydrothermal processes, multizoned zircons were also noted in the pyterlite host rocks from Hevonniemi and Haikonvuori quarries (both with cavities).

The following stages are suggested for the cavity crystallization in Haikonvuori. First, the cavity spaces with their pegmatitic rim zone formed in a closed system under the influence of the autoclave effect (cf. Kosukhin 1978). As the temperature fell contraction fractures were formed. The cavities and fractures were then partly filled with material deposited from at least two hydrothermal and one supergene fluid types. The Haikonvuori cavities are thus considered primary but their filling is largely 
secondary. Haapala (1977) drew the same conclusion from the microscopic, chlorite-filled miarolitic cavities of the Väkkärä rapakivi granite in southwestern Finland. Indications of pocket clays of supergene origin has recently been obtained from Californian pegmatites by Foord et al. (1986).

Quartz crystals are interpreted as having formed during the first hydrothermal stage. The temperature varied from $312^{\circ}$ to $464^{\circ} \mathrm{C}$ according to fluid inclusion data, and the fluid pressure was most probably in the range $0.1-1$ $\mathrm{kb}$. Molybdenite and calcite were deposited from later hydrothermal fluids. During this stage some of the earlier crystals were factured and etched. Fluid inclusions set the minimum temperature of this hydrothermal fluid at $137^{\circ}-167^{\circ} \mathrm{C}$. The latest supergene (?) fluid type is only found in monophasic inclusions and therefore is not suited to inclusion thermometry. Nevertheless, it could be shown that part of the chloritic material was deposited contemporaneously.

Chamber pegmatites, comparable to the Haikonvuori cavities in their mode of occurrence, mineral content and fluid inclusion

\section{References}

Aines, R. D. \& Rossman, G. R., 1986. Relationships between radiation damage and trace water in zircon, quartz, and topaz. Am. Mineral. 71, 1186-1193.

Augustithis, S. S., 1973. Atlas of the Textural Patterns of Granites, Gneisses and Associated Rock Types. Elsevier, Amsterdam, 378 p.

Carstens, $H$., 1968. The lineage structure of quartz crystals. Contrib. Mineral. Petrol. 18, 295-304.

Černý, P., 1982. Anatomy and classification of granitic pegmatites. In Černý P. (Ed.) Granitic Pegmatites in Science and Industry. Short Course Handbook 8. Mineral. Ass. Canada. Winnipeg, pp. 1-39.

Dennen, W. H. \& Blackburn, W. H., 1970. Aluminium in quartz as a geothermometer. Contrib. Mineral. Petrol 27, 332-342.

Eadington, P. J. \& Wilkins, R. W. T., 1980. The origin, interpretation, and chemical analysis of fluid inclusions in types, have been described from the Ukraine by Zakharchenko (1971). These chamber pegmatites, located on the southwestern border of the Korostensky rapakivi massif, are worked for gem-quality topaz and beryl, fluorite and optical-grade quartz. The isotope ages of the Korostensky and Wiborg rapakivi massives are similar, being $1750 \mathrm{Ma}$ (Semenenko et al. 1968) and 1700-1640 Ma (Vaasjoki 1977) respectively. According to Černý (1982), the chamber pegmatites in shallow granite massives are characteristic of their contact areas.

Acknowledgements. In 1981 Mr Seppo Leinikka, a teacher from Virojoki, brought some crystals from the cavities in Haikonvuori quarry to the Geological Survey of Finland for identification and provided the impetus for our investigation. The favourable attitude of Mr Paavo Varis of the Baltic Granite Co. towards our work made the collecting of field data and crystal specimens possible. The analytical skills of Mr Väinö Hoffren, Mr Gustaf Wansen and Mrs Mervi Wiik all of the Geological Survey of Finland, were indispensable and are gratefully acknowledged. We also thank Dr Matti Vaasjoki, likewise of the Geological Survey of Finland, for critically reading the manuscript and for suggesting many improvements. minerals. CSIRO, Inst. Earth Res. Tech. Commun. 69, $30 \mathrm{p}$.

Feves, M.; Simmons, G. \& Siegfried, R. W., 1977. Microcracks in crustal igneous rocks: Physical properties. In Heacock, J. G. (Ed.) The Earth's Crust: Its Nature and Physical Properties. Geophys. Monogr. Ser., 20. Am. Geophys. Union, Washington, D. C., pp. 95-117.

Foord, E. F.; Starkey, H. C. \& Taggart, J. E., Jr., 1986. Mineralogy and paragenesis of "pocket" clays and associated minerals in complex granitic pegmatites, San Diego County, California. Am. Mineral. 71, 428-439.

Frondel, C., 1962. Silica Minerals. Vol. III, The System of Mineralogy. Seventh Edition. Wiley, New York, 334 p.

Fyfe, W. S.; Price, N. J. \& Thompson, A. B., 1978. Fluids in the Earth's Crust. Developments in Geochemistry 1. Elsevier, Amsterdam, 383 p.

Goldsmith, J. R. \& Laves, F., 1954. The microcline-sanidine stability relations. Geochim. Cosmochim. Acta 5, $1-19$. 
Gromet, L. P. \& Silver, L. T., 1983. Rare earth element distributions among minerals in a granodiorite and their petrogenetic implications. Geochim. Cosmochim. Acta 47, 925-939.

Gübelin, E. J. \& Koivula, J. I., 1986. Photoatlas of Inclusions in Gemstones. ABC Edition, Zürich, 532 p.

Haapala, I., 1977. Petrography and geochemistry of the Eurajoki stock, a rapakivi-granite complex with greisen-type mineralization in southwestern Finland. Geol. Surv. Finland, Bull. 286, 128 p.

Haas, J.L., Jr., 1971. The effect of salinity of the maximum thermal gradient of a hydrothermal system at hydrostatic pressure. Econ. Geol. 66, 940-946.

Härme, M., 1980a. General map of Pre-Quaternary rocks, sheets C1-D1, Helsinki. General geological map of Finland 1:400 000.

-; 1980b. Kivilajikartan selitys, lehti-sheet C1-D1 Helsinki (in Finnish with English summary). General geological map of Finland 1:400 000. 95 p.

Joshi, M. S. \& Taku, R. K., 1972. Development of (120) prism faces of natural topaz. Am. Mineral. 57, 18841889.

Kennedy, G. C., 1950. A portion of the system silica-water. Econ. Geol. 45, 629-653.

Kosukhin, O. N., 1978. On the fluid pressure in the formation of pegmatites. Sov. Geol. Geophys. 19(2), 124126.

London, D., 1986. Formation of tourmaline-rich gem pockets in miarolitic pegmatites. Am. Mineral. 71, 396-405.

Manning, D. A. C., 1983. The effect of fluorine on the structure of hydrous aluminosilicate melts (extended abstract). Bull. Minéral. 106, 213-214.

Miller, C. F. \& Mittlefehldt, D. W., 1982. Depletion of light rare-earth elements in felsic magmas. Geology 10, 129-133.

Mittlefehldt, D. W. \& Miller, C. F., 1983. Geochemistry of the Sweetwater Wash Pluton, California: Implications for "anomalous" trace elements behaviour during differentiation of felsic magmas. Geochim. Cosmochim. Acta 47, 109-124.

Nassau, K., 1983. The Physics and Chemistry of Color. Wiley, New York, 454 p.

Olsen, K. I. \& Griffin, W. L., 1984. Fluid inclusion studies of the Drammen Granite, Oslo Paleorift, Norway. Contrib. Mineral. Petrol. 87, 15-23.

Phillips, Wm. R. \& Griffen, D. T., 1981. Optical Mineralogy. The Nonopaque Minerals. Freeman, San Francisco, $677 \mathrm{p}$.
Pichavant, M., 1979. An experimental study at high temperatures and pressures of the role of boron in some silicate systems. Petrogenetic and metallogenetic implications. Sciences de la Terre, Série "Informatique Géologigue”, 13, 41-47.

Potter, R. W., III, 1977. Pressure corrections for fluid-inclusion homogenization temperatures based on the volumetric properties of the system $\mathrm{NaCl}-\mathrm{H}_{2} \mathrm{O}$. J. Res. U. S. Geol. Surv. 5, 603-607.

Richter, D. \& Simons, G., 1977. Microcracks in crustal igneous rocks: Microscopy. In Heacock, J. G. (Ed.) The Earth's Crust: Its Nature and Physical Properties. Geophys. Monogr. Ser., 20. American Geophysical Union, Washington, D. C., pp. 149-180.

Roedder, E., 1984. Fluid Inclusions. Reviews in Mineralogy, 12. Mineral. Soc. Am. Washington, D. C., 644 p.

Semenenko, N. P., Scherbak, A. P., Vinogradov, A. P., Tougarinov, A. I., Eliseeva, G. D., Cotlovskaya, F. I., \& Demidenko, S. G., 1968. Geochronology of the Ukrainian Precambrian. Can. J. Earth Sci. 5, 661-671.

Vaasjoki, M., 1977. Rapakivi granites and other postorogenic rocks in Finland: their age and the lead isotopic composition of certain associated galena mineralizations. Geol. Surv. Finland, Bull. 294, 64 p.

Vorma, A., 1971. Alkali feldspars of the Wiborg rapakivi massif in southeastern Finland. Bull. Comm. Geol. Finlande 246, 72 p.

-; \& Paasivirta, T., 1979. Contribution to the mineralogy of rapakivi granites: I. Zircon of the Laitila rapakivi, southwestern Finland. Geol. Surv. Finland, Bull. 303, $40 \mathrm{p}$.

Wahl, W., 1925. Die Gesteine des Wiborger Rapakiwigebietes. Fennia 45(20), 127 p.

Webster, R., 1983. Gems. Their Sources, Descriptions and Identification. Fourth edition (revised by Anderson, B. W). Butterworths, London, 1006 p.

Zakharchenko, A. I., 1971. On time and physico-chemical conditions of mobilization, transport and precipitation of tungsten and tin in postmagmatic processes (exemplified by intragranitic chamber pegmatites). In Mineralogy and Geochemistry of Tungsten deposits. Materials of 2nd all-Union Symposium on Mineralogy, Geochemistry and Genesis of Tungsten Deposits of USSR, Leningrad, Leningrad Univ. Publ. House, pp. 287-306. (In Russian; translated in Fluid Inclusion Research - Proc. COFFI 6, 191-194, 1973.)

Manuscript received April 11, 1985 